https://doi.org/10.3727/152599519X15506259856174

MS 187043 accepted for publication in Event Management

\title{
WACKINESS AND EVENT MANAGEMENT: THE CASE OF THE WORLD
}

\section{ALTERNATIVE GAMES}

Lucia Aquilino, Lecturer, Events Management, Faculty of Business Law and Social Sciences, Birmingham City University, 4 Cardigan St, Birmingham, England, B4 7BD, United Kingdom, Email: Lucia.Aquilino@bcu.ac.uk

Corresponding Author, Nicholas Wise, Senior Lecturer, Tourism and Events Management, Education, Health and Community, Liverpool John Moores Uniyersity, IM Marsh Campus, Barkhill Road, Liverpool, England, L17 6BD, United Kingdom; Telephone: +44(0)747 687 0170; Email: N.A.Wise@LJMU.ac.uk

John Harris, Associate Dean, Research, Glasgow School for Business and Society, Glasgow Caledonian University, 70 Cowcaddens Road Glasgow, Scotland, G4 0BA, United Kingdom; Email: John.Harris@gdu.ac.uk 


\begin{abstract}
The World Alternative Games (WAG) is a biennial event which takes place in Britain's smallest town. This paper considers the ways in which wackiness is central to event spaces within the town of Llanwrtyd Wells, Wales. Based on a social constructivist approach, this work sheds light on aspects of the concept development, planning and organisation of events within a particular locale. It shows how wackiness is an important element of the event management development in the town and a key part of wider rural tourism development.

Keywords: Rural, Tourism Development, Wackiness, Wales.
\end{abstract}




\section{WACKINESS AND EVENT MANAGEMENT: THE CASE OF THE WORLD}

\section{ALTERNATIVE GAMES}

Event tourism is contributing to destination development by increasing competitiveness and guiding economic, social and cultural impacts in local communities (see Getz \& Page, 2016; Gibson, Kaplanidou \& Kang, 2012; Kelly \& Fairley, 2018; Laing, 2018; Wise \& Harris, 2017; Wise \& Harris, 2019). Much research has addressed mega- and hallmark-events in relatively mature tourism destinations, whereas more recent studies have also focused on smaller rural destinations (Alves, Campón Cerro \& Ferreira Martins, 2010; Perić, Đurkin \& Wise, 2016). In line with the focus of this paper, research on small-scale events and the role that they play in rural tourism development is emerging and putting alternative tourism and event strategies in the spotlight.

This paper focuses on the World Alternative Games (WAG), a biennial event held in Llanwrtyd Wells in Wales (Britain's smallest town). Tourism and event strategies have played an important role in putting the place on the map and attracting visitors to this part of Wales (see Harris, 2013). The aim of this research is to explore meanings of wackiness from a community events management context. This paper adopts a social constructivist approach to explore mechanisms of tourism development boosted by the World Alternative Games. In particular, it explores the ways in which 'wackiness' and rural creativity shape alternative event management and organisation processes.

\section{SMALL-SCALE EVENTS AND THE NOTION OF WACKINESS}

Small-scale events do not always require significant investments in infrastructures to produce benefits for the host destination. Whilst events may sometimes provide an economic boost for the host destination, they may also encourage sustainable tourism development, 
promote the utilisation of local resources and encourage local community involvement (Gibson et al., 2012; Ziakas \& Boukas, 2016). In an increasingly competitive events environment, uniqueness is essential, because it helps define an event—making it synonymous with a place. Therefore, it can be argued event tourism activities can also be viewed as sociocultural practices that tend to be based on local values and local initiatives.

Rural areas increasingly seek tourism opportunities to revitalise the local economy, often as a response to declining agricultural yields, regional deindustrialisation and generational demographic change (Daugstad, 2008). In organising and offering tourism products based on local heritage and values, rural communities tend to show a deep understanding of the emerging needs of the current tourism markets (Stolarick, Denstedt, Donald \& Spencer, 2010). Thus, rural areas have become sanctuaries, or retreats away from the crowded, noisy cities. However, rural areas can also offer tourism experiences which go far beyond tranquillity-as observed in the case of the WAG.

Market niches involve seeking 'alternative' routes and routines beyond (any) established tourism offerings (see Daugstad, 2008). But the response is the need to keep up with the rapid pace of change, because if investments and developments are ignored, a place will risk stagnation (Wise \& Harris, 2017). The careful organisation of infrastructure, activities and accommodation can promote destination development; however, inconsistencies between tourism interests and tourism offerings can create unusual market trends. Interplays of usual and unusual components affecting tourism and events include the inception of activities (which have nothing to do with leisure into a festival context), casual creation of an event space which gives voice to inner instincts and feelings of different stakeholders (e.g. eventgoers and organisers) 
instead of relying on tourism structured mechanisms or themes clearly are factors creating the unusual, or the 'wacky' in an event context (see Yeoman, 2013).

The unusual, or wacky, in an events context, can transcend plans and expectations in an industry which tends to be designed, planned, controlled and managed based on specific profitmaking interests (Yeoman, 2013). Thus, wackiness seems unpredictable, but where successful it may establish a market-niche and contribute to destination branding. Generally, the term 'wacky' refers to something distinctly different (Collins Dictionary, 2017). Therefore, it could be assumed that WAG uses wackiness to distinguish itself to promote destination development. WAG echoes the 'wacky' branding strategy adopted by a South African wine festival, to stand out among related events in the region (see Saayman, Saayman \& Joubert, 2012). As such, the term wacky is considered a marketing tool for attracting attention and is arguable more important in rural areas where event organisers may need to work harder to promote the destination and deliver an event on a smaller budget.

\section{MANAGING AND DEVELOPING RURAL EVENTS}

Rural areas, in an event management perspective, can bring both advantages and drawbacks. In fact, in such a context, a tourism product can be easily managed and controlled, but when looking closer to certain aspects like local partnerships or support of local people in general, some issues may emerge. Higham and Ritchie's (2001) study on festivals and rural events development, and Ziakas and Boukas' (2016) work on sport events in small islands, show how host rural destinations struggle with understanding trends, combining resources and skills and consistently following specific directions. By focusing closely on organisation, certain aspects which are strictly related to the management, of any event, tend to emerge though the complexity of these changes according to the scale itself, whether, large or small in scale. 
Resources, both human and endowed, the contributions of key-stakeholders (and relationships among them), as well as processes, must coalesce. These are especially important for rural events to take shape because there is not always ample or adequate supply across certain areas which might be taken-for-granted in cities (Ziakas \& Boukas, 2016). Understanding all these aspects is something that challenges event managers in rural communities, because local residents tend to be deeply involved in the event organisation (Đurkin \& Wise, 2018; Perić et al., 2016; Piazzi \& Harris, 2016). Compared to major events, smaller events in rural areas may appear manageable given they do not require large investments, new infrastructures or involve complex relationships across different governance levels (Alves et al., 2010; Gibson et al., 2012). However, certain activities require understanding the potential of local resources, or how to use them, in order to develop an event that will interest tourists and satisfy economic/financial demands (Higham \& Ritchie, 2001). When focusing on tourism development, competition and competitiveness need to be considered in relation to developments and any other event offerings in the surrounding areas. Generally, when a tourism product is planned and developed in a rural locale (such as a small town or village), local resources and skills of host communities (comprising social and human capital) are contributing assets (Piazza \& Harris, 2016).

The local community takes on key decisive roles, as participants and stakeholders (see Perić et al., 2016). Amongst these roles, the local community acts as a social and organisational system engaged in interactions and debates which encourage or enhance relationships within it. In other words, community members can boost civic pride, increase social capital and create economic diversity (Alves et al., 2010). Before achieving the desired development, a rural community faces several challenges. One of these is ensuring that the goals of the event and any related tourism development are accepted by community members, and that these, somehow, 
reflect local values and/or local interests (Derrett, 2003; Marsden-Heathcote \& Langdon, 2018; Misener \& Mason, 2006). Furthermore, developing a rural event can be a very slow process given the different demands and priorities among community members and the provision of services required to deliver a rural tourism experience (see Perić et al., 2016).

A successful community-based event can be very difficult to achieve when participation of locals tends to be quite limited (see Idziak, Majewski \& Zmyślony, 2015). In discussing the key stages through which community participation in a tourism development context ideally occurs, Okazaki (2008) outlines the importance of considering community empowerment as the highest level of engagement of locals as this encompasses the decision-making power which is the key responsibility of a stakeholder who is expected to lead a development. When looking at tourism/event developments in rural areas, participation and empowerment seems difficult to distinguish. Community participation is considered a valuable asset. Therefore, the (rural in this case) community tends to be responsible for prompting and fostering local involvement, not only in the organisation, but also through delivery. Therefore, a community assembles resources and distribute power, define responsibilities, informs, shares, negotiates directions and outcomes (see Okazaki, 2008). Understanding local resources, and particular economic, environmental and social situation is necessary to reach potential and see immediate results from tourism/event activities for the benefit of the whole community — which means visions and directions and community empowerment and participation shaped accordingly (Okazaki, 2008).

To enhance the delivery of events/tourism, collaboration between locals, business owners and any other indirect stakeholders need to emerge - even if they are not primarily involved in the delivery. The development of local small businesses is likely to be (re)enhanced and needs and interests of locals are likely to be considered in tourism development and planning — so as to 
encourage the engagement of residents and non-residents (e.g. volunteers, producers, businessmen). This helps to shape and build local capacity in rural areas by emphasising community values and skills which can lead to new or re-established bonds regionally with geographically proximate communities to develop competitive products (see Đurkin \& Wise, 2018).

\section{METHODOLOGY}

Tedlock (2005) argues that, through interaction and activity, people construct and perform their way of being and culture as social actors. Holstein and Gubrium (2008, p. 374) add that fieldwork is about understanding "what is going on" to understand "how social realities are produced, assembled, and maintained." The first author undertook ethnographic observation at the 2016 World Alternative Games, whilst the co-authors had undertaken similar work at the first two events (2012 and 2014). The data presented in this paper draws upon the fieldwork undertaken in 2016.

This case study attempts to understand 'what' the WAG represents and 'how' and 'why' things occurred within the context of this rural event to explore peculiarities embedded in its particular spatiotemporal context. Based on the social constructivist perspective, the spatiotemporal context defines peculiarities of the case study. Moreover, and within this study, key stakeholders share their insights which were also collected through semi-structured interviews. The social constructivist premise is therefore dynamic. An event such as the WAG was itself a construct made up of, and resulting from, (inter)actions of people in a setting during activities.

Ethnographic techniques provide opportunities to look in-depth at a particular case. In recent years scholars have employed ethnographic techniques to undertake research into a range 
of different events (see Holloway, Brown \& Shipway, 2010; Jaimangal-Jones, 2014).

Participation in WAG activities involved attending events (spectating, playing games, volunteering). Interviews allow for perceptions and reflections about the case to become unveiled (see Holstein \& Gubrium, 2008). Observations contributed to develop an in-depth understanding of the case through capturing elements that could not emerge across formal interviews (Atkinson \& Hammersley, 2007; Patton, 2015; Stake, 2005) to help capture meanings constructed beyond the verbal interactions between the researcher and participants (Yin, 2014). Recent research highlights the importance of looking beyond event impacts and focusing more at looking into what people do at community events (Duffy \& Mair, 2018). Community members, event organisers, volunteers, media people, owners of local businesses, councillors, participants and spectators were all part of the research study where semj-structured interviews with a range of stakeholders took place across a two-week period. Narrative and thematic analytic approaches helped identify themes contents and narrative strategies.

\section{CONTEXT: UNDERSTANDING THE WORLD ALTERNATIVE GAMES}

The WAG was held for the first time in Britain's smallest town in 2012. This was an important year for Great Britain and Northern Ireland as London (the largest city in the UK) hosted the Olympic Games and put Britain in the global spotlight that year. Mostly based on the use of local skills, facilities and sponsors, the WAG was purposely first presented as an alternative to the Olympic Games. This helped to create a narrative for the WAG that moved away from the medal table and soft power diplomacy of Olympic sport to focus instead on the areas of participation and community development. By positioning itself as being very different to the Olympic Games, which at the time were the subject of much negative commentary, the 
WAG was able to cleverly turn this into something that focused on what events could do (as opposed to the prevailing narrative of what they would not do).

In Llanwrtyd Wells, the Olympic flame is replaced by sulphur water that people ceremonially dressed up as Ancient Roman heroes riding mountain bike chariots take from the monumental fountain in the town centre where it flows for two weeks until the end of the games (World Alternative Games, 2016). The ethos of the Olympics and of the unique and sacred force of athletes running by holding the flame, tends to be taken apart and reconstructed mainly through the meanings of the local heritage and of the past of Llanwrtyd as a spa town (see World Alternative Games, 2018). The 'Corinthian spirit' of the WAG offers a more tangible version of the early ideologies of Olympism which promotes life, culture and education and respect for ethical principles.

WAG promises individuals, regardless of boundaries and differences, the opportunity to engage in 'wacky' activities. It is based around the notion that "Taking part is more important than winning" (World Alternative Games, 2016, online). This is the driving ethos of this event where participation and developing a sense of community is regarded as more important than winning or losing. Of course, the ideology of Olympism as outlined above had changed markedly by the time that London hosted the 2012 Olympic Games. The Olympics had long been used for political gain (e.g. Berlin in 1936) and the boycotts of 1980 and 1984, at a time of heightened tensions between the USA and the USSR, saw significant changes to the games. The increased commercialisation of the event since the 1984 'Hamburger games' in Los Angeles also rapidly reframed the whole idea of the Olympics and the underpinning ideology of Olympism (see Rojek, 2013; Lenskyj, 2008). 
There is also a regional and national context to acknowledge here that became part of the discourse surrounding London 2012. This was developed and presented as very much a 'British' bid although the underlying tensions between some of the constituent parts and the changing political landscape cannot be ignored. Some football matches were staged in other cities in England and in Glasgow (Scotland) and Cardiff(Wales) as a means to symbolically make this a 'British' games (see Vincent, Hill, Billings, Harris \& Massey, 2017). The perceptions of 'very little of the action taking place in Wales' (World Alternative Games, 2018) during the bidding and the planning process of London 2012 despite the promoted strategies to enhancing the visibility of the whole Britain and the tourism offering of all the nations in Britain as illustrated in the strategic plan of London 2012 (see VisitBritain, 2012) prompted action in Llanwrtyd Wells. This is outlined in the following extract from the World Alternative Games $(2016$, p.8) brochure

The idea for the Games was born after it was announced that London would be hosting the Olympics in 2012. As one of the greatest sporting events on the calendar, it seemed a wasted opportunity not to hold some sort of celebration in Llanwrtyd to commemorate this.

This event placed itself into a ten-year strategic plan set up by the Welsh Assembly Government (2008) which looks at events as a tool to enhance the reputation of the country in the global context, to create economic opportunities, and to raise the profile of Wales as a host and tourism destination. In line with this goal, the 2012 WAG managed to attract international media coverage (e.g. it was covered by media in the USA, Australia, and Russia) and featured in national news stories across different parts of Britain including a sizeable segment on the popular 
BBC Breakfast show. A key area that will be developed in this paper, and a topic that has received little attention in the event management literature to date, is wackiness.

\section{A WACKY WORLD}

\section{Local Wackiness as an Event Concept and Experience}

During the WAG, the attitude of visitors and people involved in the organisation of the events clearly differed from that of some of the spectators who looked and confirmed to be puzzled and surprised at the same time. 'It's unbelievable' is a frequent expression used by people there when they first encountered the event. We could see the most unusual objects utilised for competitions like stiletto shoes for running, hay bales for throwing, shopping trolleys, strollers and chairs for certain races, and we could find ourselyes in the most unusual places for holding competitions like a bog in a muddy field. We could feel the efforts and the enjoyment of the wives while dragging their husbands over a slippery tarpaulin covered in detergent. We could hear WAG organisers shouting to attract more competitors or announce the beginning of an activity/game. This then was a world away from the increasingly sanitised and stage-managed events that make up a sizeable portion of the events world in contemporary times. We could cheer performers, witness and judge their performances becoming actively involved in a number of different ways We could also become competitors unexpectedly. Certainly, our roles could be compromised by changes or unexpected events like the rain or a missing competitor but these roles were fluid and focused on participation not performance.

Liu, Sparks and Coghlan (2017) argue the stimulation of senses in an engaging tourism or event experience find here a further foundation. An interplay of usual and unusual factors, tangibles or intangibles (e.g. objects, actions, situations), making the usual unusual and the unusual usual, as outlined by Yeoman (2013), is the process through which the concept of 
wackiness took shape. The perceived peculiarity was instilled by what made the everyday life of a rural place an ordinary way of life. Jen said that 'every two years I just look forward to having two weeks in Wales when I just could act like a loony' and further noted that:

You do things here that you would not dream doing normally. They provide an opportunity to have a go to do some races which you would not have the opportunity to do anywhere else. And people come from far away to take part.

But it's all done tongue in cheek, you know, this is a phrase that we use to describe, you know, something which is not that serious. Yes, that's it.

Jen considered wackiness as a motivation for attending and participating in WAG. Lucy tried to tie meanings related to the participants' engagement and explained the extent to which the activities in the WAG differed from other activities:

Why do people climb mountains? Because they can, I suppose, because it's there. It is the challenge; it is unique, absolutely unique. It's tough and crazy and they can say 'I have done it!' And some come back, and some people are very competitive and they want to be able to do it and to get their time they want to be able to win and there are a lot of people who think that they can win because they don't realise how hard it is.

Lucy referred to a specific well-established sport activity (climbing) in order to strategically develop an explanation of the bog snorkelling, one of the main WAG activities. The reference to a sport context to make sense of WAG wackiness tended to be quite frequent in the respondents' answers. Indeed, respondents drew on elements embedded in sport activities to develop an understanding of factors of the WAG. 
The WAG was not seen as a serious competition because it was done 'tongue in cheek', it was not about winning but it was about doing something without minding too much, it was not about being competitive but being 'loony' (Jen). The goal was not necessarily about getting a medal but having fun. In referring to the wacky experience of participants, Pamela added:

They want to try something a little bit different, something that they have never done before $[\ldots]$ the 'water slide' for instance, people living in cities do not have things like that. People like to let themselves go and probably be children again so it can be an excuse just to do what they feel like and not be constrained, you know, being normal (laugh).

Certainly, the opportunity to engage in something which differs from everyday life routine was a strong point made by most respondents. The WAG experience among eventgoers seemed to go beyond the search of fun and enjoyment to challenge the status quo.

\section{Into the Rural}

Bertella (2014) shows how engagement in sport event activities in rural areas stimulates all the senses. Loureiro (2014) suggests that such an emotional connection can also result into a long-term attachments to the rural landscape. The emotional connections occurring across WAG seemed to be part of a specific process. Many studies focus on the (co)creation of an event experience and demonstrate how physical and interactional components making up the tourism experience are essential for a certain symbolic process, a sort of an attractive and interactive relationship between this and the tourists to deploy (see Davis, 2017; de Geus, Richards \& Toepoel, 2016). As such, wackiness seems to represent such a symbolic process enriched by physical and interactional components. Based on these reflections and interpretations, the rural 
wackiness making up the WAG event concept is clearly the relationship or the perception to which the stakeholders involved were highlighting:

I don't know, everybody that comes and speaks to me just says that they can't believe it really, how it goes and, you know, how much we do, you know. What they really like is the uniqueness, you know and it's so different than anywhere else. That's the people I know, everybody just can't believe it and it is, when you look at it, it is a bit wacky, isn't it? (Rose).

Also, the deep awareness of how perceptions of peculiarity can make a difference in an event context seemed to nurture the WAG concept as outlined by one of the organisers of the event:

We have, we run quirky events here, all strange events; so, we have our background of, our Alternative Games have to be fun and quirky and generally outdoors. So, yes, we want people to come down and try things and have a good time. Two years ago we'd been voted the most fun event to take part in Europe and we like our tag, it's good.

The WAG concept seemed to gain distinctiveness by instilling perceptions of peculiarity and by delivering moments of co-creation which distinguished themselves for their unusual content. Clearly, the awareness of having something which could be perceived as being peculiar was strategically deployed to gain a positioning in the wider British tourism context in 2012: When we heard that the Olympic Games were going to London in 2012, I spoke to the managing director of the Tourism Board, Welsh Tourism Board, and I said that nothing, no events were coming to Wales at all during the Olympic Games. So I said, what I suggested to him was we'd run our own World Alternative 
Games using our fun and quirky events and we'd add a lot more and we would have an alternative game to the Olympic Games (Percey).

Certainly, London 2012 acted as a trigger. However, the processes nurturing it neither started nor ended in 2012, as evidenced by the following quote from one of the organisers mentioning an event that had been staged in the town for a number of years:

spoke to one of the local huntsmen in the pub and then they all bet on to see who would finish first if it was a man on horse or a man running and that's when the first run started with the 'man versus horse'. And then, thought they should put on something every year, or every two years different things and we had a committee meeting, somebody said 'I don't know, all I have got is a bog, shall we come up with some ideas of using that bog?' So we change it in to a diving bog and still goes on!

Many others referred to the same anecdote when talking about the event development and this seems to shed light on the fact that the WAG concept was not purposively thought of or designed. In other words, the background to wackiness and the WAG concept were simply the result of daily meetings and interactions which have nothing to do with the work of managers dealing with the design or planning of tourism and event experiences. This somehow challenges practices like obserying the standards of the experience economy and calculating any single aspect of an event before it is delivered, which de Geus et al. (2016) define as relevant for an event experience to be successful. The wackiness, which is not planned, seems to be lived as part of the everyday life. 


\section{It's not Unusual...}

According to some local people, the town has always been the home of wacky ideas as the rural way of life has always stimulated the creativity of the local people. The fact that there is a sculpture honouring Screaming Lord Sutch, founder of the Monster Raving Loony Party and one of the most eccentric figures in twentieth-century British politics, reflects this well. Lord Sutch was a supporter of the annual man versus horse race in the town. Based on local stories, pertaining to rural life in Llanwrtyd Wells, the amount of spare time that some people have at their disposal is filled up searching for or the reusing objects found in nature (or available in town) to develop leisure activities. Making obstacles with wood, ropes and tree branches, jumping on an inflatable boat in order to glide on a snowy steep ground, and taking apart an old car to reassemble it into a dune buggy are just a few examples. These examples shed light on the fact that creativity goes hand-in-hand with rurality

Here, rurality becomes an event stage, with scenery and resources as its tools for event activities. However, in this particular case, rurality seemed to be much more than that. It was a sort of attitude which mergedinto a creative process leading to peculiar leisure activities like events. In other words, the local creativity was a sort of projection of how rurality as a physical and social space was experienced and lived. The experience of a space, and interactions with the landscape contribute to the construction of its place and event meanings (see Bertella, 2014; Derrett, 2003).

Creativity was embedded, not just purposively staged as a form of rurality, but instead nurtured by symbolic connections that locals developed through immersion in particular spaces. This embedded creativity, as a boost of and as a result of the wacky process underpinning WAG, clearly tended to act as a key factor of development. It is widely acknowledged that destinations 
need to reinvent themselves in order to proliferate and build new distinct events (e.g. Mackellar $\&$ Nisbet, 2017). If, in a context in which saturation follows the same fast pace of development, creativity needs a certain environment made up of constantly advanced expertise, facilities and amenities in order to accelerate this process, the resources needed may be growing, accordingly. Instead, when creativity is instinctively produced and does not rely on any complex forms of technology in order to be further stimulated or become more productive, then fewer resources are needed. Wacky creativity, turning usual into unusual, could be the emergence of a trend in how rural events are organised to create new economic activity in rural locales.

Despite the creativity, locals played a leading role in the WAG concept, but the games were not just the product of local wacky ideas:

We had a look around of all things that take part in Britain and all things that take part abroad and pulled as many together as we can. So, we had, 'wife carrying' which comes over from Finland and we had the world champion who came over the first year. Certain, we have things like that. We have 'Finger Jousting' which comes from America, we have 'Ping Pongo' which originated in Argentina but it was brought to us by an Argentinian who lives now in Norway. So, we have people holding their events and coming to us. (...)Yeah, we pull them in from everywhere. We have worm charming which comes from Cheshire, we have lots of different things which come from different parts of the country which we pull all together (Jack).

Intersections of creativities seemed to take place in WAG resulting not only in the peculiarity of the event experience delivered in Llanwrtyd Wells, but also in the development of collaborations between local and non-local event organisation groups, mentioned by one of the organisers: 
It's just an experience, something that they can sort of take with them and maybe try elsewhere, you know, some came down last weekend, they'd said that 'we're staying on Monday, not too far away', they'd actually heard about our games, what we are going to do for the week, they set up their own sort of games, you know, wacky sort of games as well, once they heard we were where we were, they came down to see what we were doing and to see if they could get some ideas and talk to them which I did, so we've got a couple of ideas from them as well, so a swap of ideas, which is great so, you know, it's the experience of actually being involved in something you can take somewhere else then.

The interactional process going on within it and supported by all the components and processes outlined above, from the intersection of symbolic connections to the creativity and the wackiness, nurtured and contributed to develop further the WAG concept. The event organisers were constantly challenged and stimulated by people attending or competing during the event and recognised that the WAG experiencel was a space of encounters which could have different values.

Events can be social products encompassing connections and interactions, but the interactional process is not limited to mere experiences. The WAG concept tended to transcend temporal and physical contexts and through encounters, a 'swap of ideas' occurred contributing to its development and complexity within Llanwrtyd Wells and across other places in different periods of time. Rose mentioned this clash of views gave rise to forms of collaboration and cooperation which are "good because then everybody can learn from everybody else and make it even (more) wackier", but also because this may help other rural towns to plan events on their own and so as to contribute to 'their economies'. In line with these arguments, a wacky creativity 
is a content which is easy to transfer or to export and such a transaction is not mediated by profitable or legal procedures which are used to protect new concepts and creations in the competitive business world.

\section{Rural Resources, Planning and Organisation}

Attendees would often become referees or volunteers, dealing with registration or arranging spaces. The Llanwrtyd Wells community appeared as a constantly developing resource which tended to develop in relation to the involvement of other people who were not necessarily part of the rural community:

It is not just people of the host community. As soon as somebody come up with some ideas we invite them to talk about it, and in events like this, and you know, this is a student dependent management, you need people and for the events held in the UK, we like to involve a lot of volunteers and the WAG is no exception. And everybody take up the cause and they have so much fun because they bring people into their town (Nick).

Becoming part of this resource was sharing skills of which the rural community of Llanwrtyd Wells could take advantage, as Andrea, another volunteer, highlighted: When we moved here, we came because it was a little bit quirky and a little bit different. We had no idea how much different and quirky it was. As soon as you're arriving in Llanwrtyd, everybody knows everything about this small village, everyone knows what your strengths and weaknesses are. Because everything's run by volunteers and we are very happy to get involved in lots of things because first of all, we've got to meet lots of people and secondly, we wanted to be part of the community. 
WAG organisation was undertaken 'by a group of enthusiastic volunteers trying their best, there isn't a professional event organising team behind it' (Andrea) and it was based on a 'suck-it-andsee' approach. The organisational activities of the WAG seemed to be based on a very rudimentary approach of arranging events:

We come up with an idea, we try it, we advertise it, we may have three coming along, or we may have 300 coming along. We don't know. Then, if it takes people's fancy here and it is advertised in the right places and at the right time, people come along. If it doesn't work after four or five attempts, we would push them aside and keep them for another time. If it does work, it just takes off. Basically, we try anything, any ideas that come along (Jack).

The organisational process was not very complex in that an event idea was turned into an occurrence within a very short period of time based on a quite straight forward logic. As Jacob noted:

The events here, the Man v Horse, first it started with fifteen runners, no 15

horses and 10 runners. Now, there's over a thousand, so it's largely developing.

The bog snorkelling started with about 10, now it's, we've got 150 at least. But

it's something that, once you realised, you try make a little bit better and various.

The organisers admitted not thinking about or working intensively on a specific objective when putting in place an event activity resulting from a quirky intuition. Based on these perspectives, the success or the failure of the WAG seemed to in some ways be left up to chance and wackiness was embedded in the way of doing event management too.

The consistency and the sequence of flawless activities like event design, operational management, and market research are such that a specific direction becomes the driving force of 
the event to be held. These activities should be essential for an event like the WAG, which seeks to attract media coverage to showcase the town itself. Despite the acknowledged relevance that these activities have in making an event stand out in a marketing context, the media coverage of WAG seemed to be quite successful due to the number of reporters working for national and international television and newspapers who went to Llanwrtyd Wells in 2016. Indeed, many would take pictures or shoot videos of the competitions. Many would interview the organisers before the events and the competitors soon after taking part in the games. This logic of doing things differently which was on the basis of every single aspect of WAG, from the way the event concept was conceived to the event organisation, somehow foreruns a sort of change or the necessity to make a change in the event industry, especially in rural contexts, in relation to how objectives and goals of tourism development are achieved.

\section{CONCLUSION}

This study explored the wackiness of the WAG and shows that the WAG concept lies betwixt interplays of the usual and unusual All objects, interactions, and processes which shaped rural life in Llanwrtyd Wells characterised the event experience-each contributing to the development of an event experienced, perceived, or purposively promoted, as wacky. Wackiness as an event process, albeit fostered by the way of life of the local community, does so that the cocreation of the experience involving all the stakeholders blurred their roles, whilst also attributing them different ones at the same time.

Wackiness stands as an alternative mechanism for tourism development and event management (in such rural locales). WAG is not the product of complex blue-printed designs and planning processes but tends to emerge from the daily encounters of people. Indeed, the uniqueness of WAG lies in the use of the creativity of the people of Llanwrtyd Wells by 
constantly interacting with the surrounding landscape. All those involved in the WAG, regardless of their roles (e.g. participant, organiser, spectator, volunteer), are an important resource in the events organisation and delivery. Through an interchange of roles, the role boundaries become fuzzy. Skills, expertise and ideas are shared and made available for the event to develop.

The people in Llanwrtyd Wells adopt a sort of 'suck-it-and-see' logic in line with the notion of wackiness encompassing every aspect of the event. Where events can be looked as opportunities to experience something which cannot normally be experienced, there may also be a focus on more stimulating tourism contexts offering different life perspectives (see Laing, 2018). Participation in the event is founded on fun, and by adding engaging wacky activities differing from more 'normal' life routines, eventgoers can unyeil (and share) their inner quirkiness. In some ways the event frees individuals from any social constraints.

Based on these arguments, this paper shows how wackiness, may set the scene for another way of thinking, planning, and organising events. The WAG does not tend to be framed into standards and structures guiding the stakeholders in the development and experience of it, but it arises as a sort of puzzle whose pieces are devised and put together by all those who want to contribute to it in any way possible. In line with Patterson and Getz's (2013) suggestion to conduct events research by scrutinising interrelationships between events and society, this paper provides new insights on organising and managing events in rural areas. Considering the managerial implications of this study, in rural areas, especially, there is a need for planners and managers to design flexible event portfolios. The findings suggest such wacky events do not necessarily stick to a particular event design, but a plan that enables eventgoers, suppliers and involved stakeholders to deliver experiences in the spaces that are more spontaneous - creating and delivering experiences based on their feeling of the ongoing situation, their instincts, and the 
dynamics of the attendees. It is therefore important to find new ways, strategies or tools that will help eventgoers co-create the event experience based on how they want to engage with wacky event experiences. To conclude, strategies and approaches taken by mangers and planners thus always need to be different and flexible, because in rural areas, there are open spaces and people who attend have different views and needs, and even the same person might change their idea or purpose for attending when participating or spectating at such wacky events. In particular, this study sheds light on how participation and creativity can contribute to the development of a ‘wacky' event. 


\section{REFERENCES}

Alves, H.M.B., Campón Cerro, A.M., \& Ferreira Martins, A.V. (2010). Impacts of small tourism events on rural places. Journal of Place Management and Development, 3(1), 22-37.

Atkinson, P., \& Hammersley, M. (2007). Ethnography: Principles in practice. London: Routledge.

Bertella, G., (2014). Designing small-scale sport events in the countryside. International Journal of Event and Festival Management, 5(2), 132-145.

Collins Dictionary. (2017). Definition of 'Wacky'. Glasgow: HarperCollins.

Daugstad, K. (2008). Negotiating landscape in rural tourism. Annals of Tourism Research, 35(2), $402-426$.

Davis, A. (2017). It wasn't me, it was my festival me: The effect of event stimuli on attendee identity formation. Tourism Management, 61, 484-500.

de Geus, S., Richards, G., \& Toepoel, V. (2016). Conceptualisation and operationalisation of event and festival experiences: Creation of an event experience scale. Scandinavian Journal of Hospitality and Tourism, 16(3), 274-296.

Derrett, R. (2003). Festivals \& regional destinations: How festivals demonstrate a sense of community \& place. Rural Society, 13(1), 35-53.

Duffy, M., \& Mair, J. (2018). Engaging the senses to explore community events. Event Management, 22(1), 49-63.

Đurkin, J., \& Wise, N. (2018). Managing community stakeholders in rural areas: Assessing the organisation of local sports events in Gorski kotar, Croatia. In A. Clarke \& A. Jepson (Eds.), Power, construction and meaning in festivals \& events (pp. 185-200). London: Routledge. 
Getz, D., \& Page, S. (2016). Progress and prospects for event tourism research. Tourism Management, 52, 593-631.

Gibson, H.J., Kaplanidou, K., \& Kang, S.J. (2012). Small-scale event sport tourism: A case study in sustainable tourism. Sport Management Review, 15(2), 160-170.

Harris, J. (2013). Sporting events, image, and identities in contemporary Wales. North American Journal of Welsh Studies, 8(1), 100-112.

Holloway, I., Brown, L., \& Shipway, R. (2010). Meaning not measurement: Using ethnography to bring a deeper understanding to the participant experience of festivals and events. International Journal of Event and Festival Management, 1(1), 74-85.

Higham, J. E. S., \& Ritchie, B. (2001). The evolution of festiyals and other events in evolution festivals in rural southern New Zealand. Event Management, 7, 39-49.

Holstein J.A., \& Gubrium, J. F. (2008). Handbook of constructionist research. New York: The Guilford Press.

Idziak, W., Majewski, J., \& Zmyślony,P. (2015). Community participation in sustainable rural tourism experience creation: A long-term appraisal and lessons from a thematic villages project in Poland. Journal of Sustainable Tourism, 23(8-9), 1341-1362.

Jaimangal-Jones, D. (2014). Utilising ethnography and participant observation in festival and event research. International Journal of Event and Festival Management, 5(1), 39-55.

Kelly, D.M., \& Fairley, S. (2018). What about the event? How do tourism leveraging strategies affect small-scale events? Tourism Management, 64, 335-345.

Laing, J. (2018). Festival and event tourism research: Current and future perspectives. Tourism Management Perspectives, 25, 165-168.

Lenskyj, H. (2008). Olympic industry resistance. Albany: State University of New York Press. 
Liu, W., Sparks, B., \& Coghlan, A. (2017). Event experiences through the lens of attendees. Event Management, 21(4), 463-479.

Loureiro, S.M.C. (2014). The role of the rural tourism experience economy in place attachment and behavioral intentions. International Journal of Hospitality Management, 40, 1-9.

Mackellar, J., \& Nisbet, S. (2017). Sport events and integrated destination development. Current Issues in Tourism, 20(13), 1320-1335.

Marsden-Heathcote, L., \& Langdon, J. (2018). Community sport event management. In R. Wilson \& C. Platts (Eds.), Managing and developing community sport (pp. 109-125). London: Routledge.

Misener, L., \& Mason, D. S. (2006). Creating community networks: Can sporting events offer meaningful sources of social capital? Managing Leisure, 11, 39-56.

Okazaki, E. (2008). A community-based tourism model: Its conception and use. Journal of Sustainable Tourism, 16(5), 511-529.

Patterson, I., \& Getz, D. (2013). At the nexus of leisure and event studies. Event Management, $17(3), 227-240$.

Patton, M. Q. (2015). Qualitative research and evaluation methods. London: Sage.

Perić, M., Đurkin, J., \&Wise, N. (2016). Leveraging small-scale sport events: Challenges of organising, delivering and managing sustainable outcomes in rural communities, the case of Gorski kotar, Croatia. Sustainability, 8, 1-17.

Piazzi, F., \& Harris, R. (2016). Community engagement and public events: The case of Australian folk festivals. Event Management, 20(3), 395-408.

Rojek, C. (2013). Event power: How global events manage and manipulate. London: Sage. 
Saayman, M., Saayman, A., \& Joubert, E.M. (2012). Expenditure-based segmentation of visitors to the Wacky Wine Festival. Tourism Recreation Research, 37(3), 215-225.

Stake, R. E. (2005). Qualitative case studies. In N. K. Denzin \& Y. S. Lincoln (Eds.), The Sage Handbook of Qualitative Research (pp. 443-465). London: Sage.

Stolarick, K., Denstedt, K., Donald, B., \& Spencer, G.M., (2010). Creativity, tourism and economic development in a rural context: The case of Prince Edward County. Journal of Rural and Community Development, 5(1/2), 238-254.

Tedlock, B (2005) The observation and participation of and the emergence of public ethnography. In N. Denzin, \& L. Yvonna, (Eds.), The SAGE handbook of qualitative research (pp. 151-171). Thousand Oaks, CA: Sage,

Vincent, J., Hill, J.S., Billings, A., Harris, J., \& Massey, C.D. (2017). "We are GREAT Britain": British newspaper narratives during the London 2012 Olympic Games. International Review for the Sociology of Sport, DOI: 10.1177/1012690217690345

VisitBritain (2012). The London 2012 Olympic \& Paralympic Games: Our story. London: VisitBritain.

Welsh Assembly Government.(2008). Event Wales: A major events strategy for Wales 20102020. Cardiff: Welsh Assembly Government.

Wise, N., \& Harris, J. (Eds.) (2017). Sport, events, tourism and regeneration. London: Routledge.

Wise, N., \& Harris, J. (Eds.) (2019). Events, places and societies. London: Routledge.

World Alternative Games. (2016). Llanwrtyd Wells: Events \& activities. Llanwrtyd Wells: Welsh Country Magazine. https://issuu.com/worldalternativegames/docs/llanwrtyd_events_brochure_issuu_02 
World Alternative Games. (2018). World Alternative Games 2018. Retrieved from http://www.worldalternativegames.com.

Yeoman, I. (2013). A futurist's thoughts on consumer trends shaping future festivals and events. International Journal of Event and Festival Management, 4(3), 249-260.

Yin, R.K. (2014). Case study research: Design and methods. London: Sage.

Ziakas, V., \& Boukas, N. (2016). The emergence of "small-scale" sport events in "small island" developing states: Towards creating sustainable outcomes for island communities. Event Management, 20(4), 537-563. 